\title{
The toxic benthic dinoflagellates of the genus Ostreopsis in temperate areas: a review
}

\author{
Stefano Accoroni, ${ }^{*}$ Cecilia Totti \\ Dipartimento di Scienze della Vita e dell'Ambiente, Università Politecnica delle Marche, via Brecce Bianche, 60131 Ancona, Italy \\ *Corresponding author: s.accoroni@univpm.it
}

\begin{abstract}
The genus Ostreopsis includes species largely distributed from tropical to temperate marine areas worldwide. Among the nine species of the genus, $O$. siamensis, $O$. mascarenensis, $O$. lenticularis and $O$. cf. ovata can produce toxins of the palytoxin group. In the last decade Ostreopsis cf. ovata and $O$. cf. siamensis originated intense blooms in all the rocky Mediterranean Sea coastal areas, typically during summer-late summer. The correct identification of Ostreopsis species in field samples is often problematic as Ostreopsis species are morphologically plastic and hardly discriminable under light microscopy and, therefore, molecular analyses are required. Ostreopsis blooms are often associated with noxious effects on health of both humans and benthic marine organisms mainly carried by aerosol and direct contact with seawater. Environmental factors have been shown to affect toxin content of Ostreopsis which generally produces more toxins per cell when growing under suboptimal conditions. O. cf. ovata is able to produce both temporary and resting cysts. In particular, the resting cysts are able to germinate in laboratory conditions for as long as 5 months after their formation at $25^{\circ} \mathrm{C}$, but not at $21^{\circ} \mathrm{C}$; the presence of a temperature threshold affecting cyst germination in the laboratory suggests that temperature represents a key factor for Ostreopsis cf. ovata bloom onset in natural environments as well. Several studies conducted to assess the role of abiotic factors (mainly hydrodynamics, water temperature and nutrients) on the bloom dynamics, revealed that the synergic effects of hydrodynamics, temperature and N:P ratios would lead the Ostreopsis blooms in temperate areas. Ostreopsis abundances showed a significant decrease with depth, likely related to light availability, although there are conflicting data about the relationship between light intensity and Ostreopsis growth in experimental conditions. The relationship between Ostreopsis blooms and salinity is not completely clear, complicated by the influence of high nutrient levels often associated to low salinity waters. Finally, Ostreopsis colonize a variety of substrata, although living substrata seems to allow lower concentration of epibionts than any other substrate, probably due to the production of some allelopathic compounds.
\end{abstract}

Key words: Ostreopsis; palytoxin; harmful algae; benthic dinoflagellates; Mediterranean Sea.

Received: October 2015. Accepted: February 2016.

\section{INTRODUCTION}

The genus Ostreopsis belongs to the family of Ostreopsidaceae (Gonyaulacales, Dinophyceae, Dinophyta). It was first described by Schmidt (1901) after the finding of O. siamensis Schmidt in plankton samples collected in the Gulf of Siam in 1900. Since then, this species has rarely been encountered in the phytoplankton, due to its predominantly benthic habit.

Ostreopsis species were reported since a long time in tropical ciguatera endemic areas, associated with the benthic toxic dinoflagellate Gambierdiscus toxicus (Ballantine et al., 1985; Carlson and Tindall, 1985; Bomber and Aikman, 1989) and, therefore, improperly considered in association with ciguatera syndrome (Tosteson, 1995). Indeed, some Ostreopsis species are toxic, but their toxins (mostly belonging to the palytoxin group) are not those implicated in ciguatera.

In the last decade, Ostreopsis blooms have become common in temperate areas as well, and regularly occur in the Mediterranean Sea during summer-autumn (Vila et al., 2001; Turki, 2005; Aligizaki and Nikolaidis, 2006; Mangialajo et al., 2008; Totti et al., 2010; Illoul et al., 2012; Ismael and Halim, 2012; Pfannkuchen et al., 2012), and in other temperate areas of the world (Chang et al., 2000; Rhodes et al., 2000; Pearce et al., 2001; Taniyama et al., 2003; Shears and Ross, 2009; Selina et al., 2014). In these areas, Ostreopsis is well-known since its blooms are often associated with noxious effects on health of both humans (Gallitelli et al., 2005; Kermarec et al., 2008; Tichadou et al., 2010; Del Favero et al., 2012) and benthic marine organisms (Pagliara and Caroppo, 2012; Gorbi et al., 2013; Carella et al., 2015). Additionally, Ostreopsis often appeared in association with other toxic or potentially toxic benthic dinoflagellates such as Prorocentrum spp., Amphidinium spp. and Coolia monotis in both several Mediterranean (Tognetto et al., 1995; Vila et al., 2001; Aligizaki and Nikolaidis, 2006; Monti et al., 2007; Mabrouk et al., 2011) and world areas (Okolodkov et al., 2007; Parsons and Preskitt, 2007; Kim et al., 2011; Selina and Levchenko, 2011). 
Given their negative implications on both marine ecosystem functioning and human health and activities, Ostreopsis blooms attracted the attention of researchers in the last decade. This paper is meant to be a narrative review of the existing information about taxonomy, geographical distribution, toxin production, life cycle and ecology of Ostreopsis in temperate areas.

\section{TAXONOMY}

There is a considerable confusion regarding the descriptions of the Ostreopsis species, since its first description carried out by Schmidt (1901): in the original drawings of Ostreopsis siamensis, both the epitheca and the hypotheca in anteroposterior view were presented but with marked different shapes (one appeared rounded and the other appeared elongated) insomuch hardly they can belong to the same cell. Much later, Fukuyo (1981) re-described $O$. siamensis and described two new species $O$. lenticularis and O. ovata. The rounded shape reported by Schmidt for $O$. siamensis was one of the main differences between $O$. lenticularis and $O$. siamensis, so probably in the original description Schmidt confused these two species. O. ovata was distinguished from the other two species by having a more ovoid shape and a smaller size. In the following years, several other species have been described by other authors: O. heptagona (Norris et al., 1985), O. mascarenensis (Quod, 1994), O. labens (Faust and Morton, 1995), O. marinus, O. belizeanus and $O$. caribbeanus (Faust, 1999) (recently, the latter three have been renamed as $O$. marina, O. belizeana, O. caribbeana, Hoppenrath et al., 2014). So, at present, nine species of Ostreopsis have been described.

In the Mediterranean Sea, only two species have been recorded until now, $O$. cf. ovata and $O$. cf. siamensis (Vila et al., 2001; Penna et al., 2005, 2010, 2012; Battocchi et al., 2010; Totti et al., 2010; Mangialajo et al., 2011; Perini et al., 2011; Mabrouk et al., 2012). The correct identification of these Ostreopsis species in field samples is often highly problematic. The most suitable taxonomical character used to discriminate $O$. cf. ovata and $O$. cf. siamensis, is the dorsoventral/anteroposterior diameter ratio (DV/AP) which is $<2$ and $>4$, respectively (Penna et al., 2005; Aligizaki and Nikolaidis, 2006; Selina and Orlova, 2010). However, O. cf. ovata cells in the Adriatic Sea (Mediterranean Sea) have a DV/AP ratio slightly higher than 2 (i.e., 2.3-2.4) (Monti et al., 2007; Guerrini et al., 2010; Accoroni et al., 2012b). Since the molecular analyses clearly confirmed the presence of only $O$. ovata species in the N Adriatic samples (Perini et al., 2011), it can be hypothesized that the Adriatic population has a different cell morphology, with cells more flattened than in other areas. These morphological problems and the lack of genetic data for the holotype specimens from which the original species descriptions of both $O$. siamensis and $O$. ovata were made, lead to the conclusion that $O$. siamensis and $O$. ovata examined nowadays should be referred to $O$. cf. siamensis and $O$. cf. ovata respectively, until more accurate morphological data and genetic sequences will be gathered to clearly define each species (Penna et al., 2005, 2010).

Given these ambiguities in defining morphological characteristics, many researchers have been induced to revise the description of Ostreopsis species by sequencing the ITS and 5.8S rDNA regions, using these data in combination with morphometric ones. Leaw et al. (2001) isolated several Ostreopsis strains from Malaysian coastal waters and showed that $O$. cf. ovata isolates were separated into two genetically distinct geographic groups, a Malacca Strait group and a South China Sea group, while there were minor morphological differences among the strains. The 5.8S and ITS sequences of these Malaysian strains differed from Mediterranean strains ones (Penna et al., 2005), suggesting a genetic variability in relation to the geographic distribution within the species. Nowadays, the ITS-5.8S and LSU rDNA allowed to distinguish various clades among the Ostreopsis species (Penna et al., 2014): the species complex Ostreopsis cf. ovata includes the Atlantic/Mediterranean/Pacific clade (i.e., isolates from Japan Sea, and Mediterranean Sea), the Atlantic/Indian/Pacific clade (i.e., isolates from Belize) and the Pacific clade (i.e., isolates from Vietnam); Ostreopsis cf. siamensis forms an Atlantic/Mediterranean clade. The $O s-$ treopsis cf. lenticularis/O. cf. labens contains isolates from Hawaii and Pacific Asia.

\section{DISTRIBUTION IN TEMPERATE AREAS}

The first record of Ostreopsis in the Mediterranean Sea dates back to 1972 in Villefranche-sur-Mer (France) by Taylor (1979). Later, O. cf. ovata was detected in 1994 along both the Italian coasts of the Tyrrhenian Sea (Tognetto et al., 1995) and the Catalan coast in Spain in 1997-1998 (Vila et al., 2001). In the last decade, Ostreopsis spp. blooms have been more intense, frequent, and widely distributed in many Mediterranean areas, including Spain, France, Greece, Italy, Algeria, Tunisia, Turkey (Turki, 2005; Aligizaki and Nikolaidis, 2006; Ciminiello et al., 2006, 2008; Riobó et al., 2006; Turki et al., 2006; Monti et al., 2007; Riobó et al., 2008; Guerrini et al., 2010; Mabrouk et al., 2011, 2012; Mangialajo et al., 2011; Illoul et al., 2012). As reported above, genetic analyses indicate that two genotypes corresponding to the morphotypes $O$. cf. ovata and $O$. cf. siamensis are present in the Mediterranean Sea (Penna et al., 2010, 2012). Along the Mediterranean rocky coasts, the genotype ovata is the most abundant and widely distributed (Battocchi et al., 2010; Perini et al., 2011). The genotype siamensis was detected along the Catalan coast, 
in the eastern Atlantic coast of Morocco, Portugal, northern Spain and southern Italy (Vila et al., 2001; Amorim et al., 2010; Bennouna et al., 2010; Laza-Martinez et al., 2011; Ciminiello et al., 2013) and its morphotype has also been reported along the northern African coast (Turki, 2005; Turki et al., 2006; Mabrouk et al., 2011, 2012). Moreover, Penna et al. (2012) found a new genotype, probably corresponding to a new species of Ostreopsis, in both the Atlantic coast (Canary Islands) and Mediterranean Sea (Greece and Cyprus).

Ostreopsis spp. have been recorded in other temperate areas as well. In Japan, toxic strains of both $O$. siamensis and $O$. ovata have been recorded not only in sub-tropical southern Okinawan waters in late 1970s (Fukuyo, 1981; Nakajima et al., 1981; Yasumoto et al., 1987) but also in the more temperate northern waters of western Kyushu, eastern Miyazaki, Kochi and Shikoku (Taniyama et al., 2003; Adachi et al., 2008; Sagara, 2008). Ostreopsis cf. siamensis cells were found in temperate New South Wales and Tasmanian waters (Murray, 2010) and, in the latter, in the gut contents of wild mussels (Pearce et al., 2001). Moreover, $O$. cf. siamensis has become a major bloom former in New Zealand, causing extensive mats covering seaweeds in the eastern Northland waters, and has been reported as far south as temperate Wellington waters (Rhodes et al., 2000, 2010; Shears and Ross, 2009); in the northern New Zealand waters also $O$. lenticularis and $O$. cf. ovata have been recorded (Chang et al., 2000). Finally, Ostreopsis cf. ovata and $O$. cf. siamensis were a constant component of the epiphytic communities during the summer-fall period in Peter the Great Bay, Sea of Japan since 2006 (Selina and Orlova, 2010; Selina et al., 2014).

\section{TOXIN PROFILE AND FACTORS AFFECTING TOXIN PRODUCTION}

Ostreopsis species produce different toxins, mostly belonging to the palytoxin group. Among the nine species of the genus Ostreopsis, toxicity has been demonstrated in $O$. siamensis, $O$. mascarenensis, $O$. lenticularis and $O$. cf. ovata (Nakajima et al., 1981; Yasumoto et al., 1987; Holmes et al., 1988; Mercado et al., 1994; Meunier et al., 1997; Lenoir et al., 2004; Ciminiello et al., 2006; Scalco et al., 2012; Uchida et al., 2013; Brissard et al., 2015; García-Altares et al., 2015). Moreover, O. heptagona was determined to be toxic as methanol extracts of culture of this species isolated from Knight Key (Florida) were weakly toxic to mice (Babinchak, according to Norris et al., 1985).

Palytoxin (PITX) has a molecular formula of $\mathrm{C}_{129} \mathrm{H}_{221} \mathrm{~N}_{3} \mathrm{O}_{54}$ and a molecular weight of $2680 \mathrm{Da}$ (Moore and Bartolini, 1981). It has been primarily isolated from the marine zoanthid Palythoa toxica (Moore and Scheuer, 1971), from which the name comes. PITX is a very com- plex molecule with both lipophilic and hydrophilic groups and is slightly less toxic than maitotoxin in total potency. The PITX analogues produced by Ostreopsis species have a similar chemical structure as the parent PITX, as well as a similar mode and site of action. Ostreocin-D was the first PITX analogue isolated from cultures of $O$. siamensis (Usami et al., 1995; Ukena et al., 2001). This compound has the chemical formula $\mathrm{C}_{127} \mathrm{H}_{220} \mathrm{~N}_{3} \mathrm{O}_{53}$ and a molecular weight of $2634 \mathrm{Da}$, a little lower than PITX. Another PITX analogue, mascarenotoxin (McTX), was isolated from $O$. mascarenensis (Lenoir et al., 2004) and $O$. cf. ovata (Rossi et al., 2010; Scalco et al., 2012). The molecular weight of the three identified mascarenotoxin congeners ranges from 2500 to $2628 \mathrm{Da}$ (Rossi et al., 2010). In addition, a third PITX analogue was isolated from $O$. cf. ovata, the ovatoxin (OvTx) (Ciminiello et al., 2008, 2010, 2012a; Rossi et al., 2010). Mediterranean cultures of $O$. cf. ovata were found to produce isobaric palytoxin, ovatoxin-a, b, c, d, e, f, $\mathrm{g}$ and $\mathrm{h}$ and mascarenotoxin-a and c (Scalco et al., 2012; García-Altares et al., 2014; Brissard et al., 2015). On the contrary, the Mediterranean $O$. cf. siamensis strain seems to be devoid of any appreciable toxicity (Ciminiello et al., 2013). Finally, ostreotoxins (produced by $O$. lenticularis) do not display the same mode and site of action as PITX-analogues and the classification of these compounds as PITX analogues is still unclear (Mercado et al., 1994; Meunier et al., 1997).

As far as the studies on the action mechanism are concerned, almost all studies refer to the commercial PITX standard (Tubaro et al., 2014). PITX targets membrane sodium-potassium pumps $(\mathrm{Na}+/ \mathrm{K}+$-ATPase) responsible for maintaining ionic gradients (Artigas and Gadsby, 2003). Characteristic aspects of PITX include delayed haemolysis with a loss of potassium, converting $\mathrm{Na} / \mathrm{K}$ pump into a non-specific ionic channel leading to the disruption of ion homeostasis exerted on excitable tissues (Habermann et al., 1981). This results in nausea, vomiting, hyper-salivation, abdominal cramps, diarrhoea, numbness of extremities, severe muscular spasms and respiratory distress (Yasumoto et al., 1986; Alcala et al., 1988; Kodama et al., 1989). On the contrary, the possible effects recorded in non-excitable cells are less clear: in this case, the toxin can affect different sets of proteins and signalling pathways, stressing the complexity of the mode of action of PITX (Bellocci et al., 2011; Rossini and Bigiani, 2011; Wattenberg, 2011). For example, protein kinases involved in the control of cell proliferation can be activated by PITX (Wattenberg, 2011), providing a possible role of this toxin in the tumour-promoting activity (Fujiki et al., 1986; Fujiki and Suganuma, 2009). However, PITX has been also shown to possess a potent cytotoxic activity (Bellocci et al., 2011).

Environmental factors (e.g. temperature, salinity, light, nutrients) and the characteristic of the strains (e.g., isolation 
site, growth phase and the age of the strain) have all been shown to affect toxin content in Ostreopsis cultures (Guerrini et al., 2010; Ciminiello et al., 2012a,b; Pezzolesi et al., 2012; Scalco et al., 2012; Vanucci et al., 2012b). Several phytoplankton species produce more toxins per cell when growing under suboptimal conditions (Johansson and Granéli, 1999a,b; Etheridge and Roesler, 2005). In the same way, some authors observed that $O$. cf. ovata isolated from both the Tyrrhenian and Adriatic Seas produces higher toxin contents per cell when growing under suboptimal temperature and salinity conditions (Granéli et al., 2011; Pezzolesi et al., 2012; Vidyarathna and Granéli, 2013), which differ among strains from different geographical areas (see Paragraph 7). On the contrary, optimal nutrient conditions seem to be required for toxin production and both $\mathrm{P}$ - and $\mathrm{N}$-depleted media decreased $O$. cf. ovata toxicity (Vanucci et al., 2012b). The growth phase affects $O s-$ treopsis toxicity as well. Although toxin production rate has been found to increase during the exponential phase (Pezzolesi et al., 2014), toxins concentration on a per cell basis increased from the exponential to the senescent phase, independently of the growth conditions (Guerrini et al., 2010; Pistocchi et al., 2011; Vanucci et al., 2012a, 2012b). This behaviour was recently explained (Pinna et al., 2015) as due to the strong influence of the internal nutrient status (i.e., carbon to nutrient ratio) on toxin synthesis. On the contrary, the toxin profile of $O$. cf. ovata was relatively stable during the growth stages and independent of culture conditions (Pistocchi et al., 2011; Scalco et al., 2012; Pezzolesi et al., 2014).

\section{VECTORS OF EXPOSITION AND EFFECTS ON ORGANISMS}

The main vectors for Ostreopsis intoxication of humans include marine aerosol (Casabianca et al., 2013, 2014; Ciminiello et al., 2014), direct contact (Tichadou et al., 2010) and the per os ingestion (the latter mainly associated to clupeotoxism syndrome, see below). Blooms of $O$. cf. ovata caused serious problems on human health, mainly due to inhalation of sea water droplets containing Ostreopsis cells or fragments and/or aerosolized toxins (Gallitelli et al., 2005; Kermarec et al., 2008; Tichadou et al., 2010; Honsell et al., 2011; Del Favero et al., 2012). One of the most intense episode occurred in summer 2005, when about 200 people exposed to marine aerosols along the Ligurian coasts required medical first aid due to similar symptoms of respiratory intoxications, and 20 persons were subjected to extended hospitalization (Brescianini et al., 2006; Durando et al., 2007). The typical intoxication symptoms of Ostreopsis aerosol and direct contact exposure (fever, dyspnoea, broncho-constriction, conjunctivitis and skin irritations) resolve within a few days.

Regarding the oral ingestion, although Ostreopsis has not been confirmed as the source of toxin in clupeotoxism yet, it was strongly suspected of that intoxication in several events (e.g., Onuma et al., 1999; Randall, 2005). Clupeotoxism is one of human intoxications due to consumption of contaminated sardines and herrings (Clupeidae) or anchovies (Engraulidae). Symptomology of clupeotoxism is similar to that of ciguatera (Yasumoto et al., 1986), though the former has a much higher mortality rate (Onuma et al., 1999). Several outbreaks were reported in tropical insular areas of the Pacific and the Caribbean during the last 30 years (Yasumoto et al., 1986; Fukui et al., 1987; Gleibs et al., 1995). Recently, clupeotoxism occurred in the southwestern Indian Ocean, mainly in Madagascar where palytoxin analogues were involved in fatalities occurred after consumption of Sardinella fish (Yasumoto, 1998; Hansen et al., 2001).

Ostreopsis toxins may contaminate seafood: ostreocin-D produced by $O$. cf. siamensis were accumulated in wild mussels (Mytilus edulis planulatus) from Tasmanian coasts (Pearce et al., 2001). Rhodes et al. (2002), feeding New Zealand mussels (Perna canaliculus), Pacific oysters, and scallops (Pecten novaezealandiae) with $O$. cf. siamensis cells detected trace amounts of palytoxinlike compounds in some of the fed animals. In the Mediterranean Sea, Aligizaki et al. (2008) analysing field samples of shellfish (Mytilus galloprovincialis, Venus verrucosa, Modiolus barbatus) reported that shellfish toxicity coincided with seasonal peaks in Ostreopsis abundance, providing the most compelling evidence to date that $O s$ treopsis-borne palytoxin analogues likely accumulate in shellfish. Although it has been shown that the oral toxicity of palytoxin and 45-hydroxy palytoxins is about 1000fold less than that observed by intraperitoneal injection (Sosa et al., 2009; Munday, 2011; Tubaro et al., 2011), a regulatory threshold of $30 \mu \mathrm{g} \mathrm{kg}^{-1}$ has been proposed for shellfish flesh (EFSA, 2009). However, the effects of the ingestion of products contaminated by $O$. cf. ovata toxin are still unknown.

Ostreopsis blooms are often accompanied by mortality of benthic marine organisms, such as sea urchins, limpets, mussels, crustaceans, holothurians, sponges and even macroalgae (Di Turi et al., 2003; Shears and Ross, 2009, 2010; Accoroni et al., 2011). In fact, several recent studies have shown that Ostreopsis toxicity affects also various marine organisms, both invertebrates and fish (Gorbi et al., 2012, 2013; Simonini et al., 2011; Faimali et al., 2012; Pezzolesi et al., 2012; Privitera et al., 2012; Carella et al., 2015), interfering with embryonic development as well (Pagliara and Caroppo, 2012).

A study carried out on natural banks of Mytilus galloprovincialis sampled during various phases of $O$. cf. ovata bloom in the north-western Adriatic Sea (Mediterranean Sea) demonstrated a significant accumulation of algal toxins in mussels exposed, which exhibited a marked inhibi- 
tion of the $\mathrm{Na}+/ \mathrm{K}+$-ATPase activity and alterations of immunological, lysosomal and neurotoxic responses (Gorbi et al., 2012).

\section{LIFE CYCLE AND CYST FORMATION}

As the largest part of marine dinoflagellates, Ostreopsis has a haplontic life cycle with a dominant motile haploid biflagellate stage (Pfiester and Anderson, 1987; Litaker et al., 2002).

The asexual and sexual reproduction of Ostreopsis has been studied mainly in Ostreopsis cf. ovata, both in the field and in cultures isolated from the Mediterranean Sea (Bravo et al., 2012; Accoroni et al., 2014). The asexual reproduction occurs with the division of haploid vegetative cells that takes place in the motile stage: cells divide by desmoschisis in the sagittal plane, with each daughter cell inheriting part of the parental thecal plates (Bravo et al., 2012).

In general, sexual reproduction of dinoflagellates usually begins with the production of gametes that can fuse with each other forming a diploid zygote. The actual details of gamete formation vary, but in any case, two haploid cells (both typically motile) fuse to yield a diploid cell. The sexual reproduction in $O$. cf. ovata has been observed in both natural and cultured populations (Bravo et al., 2012). Gamete pairs are observed in either intercrosses or intracrosses of different strains (Bravo et al., 2012) and nutrient limitation seems to stimulate sexual reproduction, which however occurs also in normal culture conditions (Accoroni et al., 2014). In O. cf. ovata, two types of mating gametes were identified: i) gametes joined by epitheca, with the point of attachment positioned almost centrally (Bravo et al., 2012), and ii) gametes joined laterally with the two cingula perpendicular to each other, with melting of the two thecae (Accoroni et al., 2014), as observed in Coolia monotis by Faust (1992). In dinoflagellates, the newly formed motile diploid cell produced when karyogamy and plasmogamy are complete, is known as a planozygote (Pfiester, 1989). The planozygote of some species undergoes meiosis in the plankton, while that of most other dinoflagellates swims for a variable amount of time (hours to weeks), sheds its flagella, rounds up, and settles to form a nonmotile hypnozygote. Hypnozygotes often differentiate into long-term resting stages (hypnocysts) that accumulate in sediments and may remain dormant for years before germinating (Wall, 1975; Anderson et al., 1987). Different types of cysts were identified for $O$. cf. ovata; some of them are non-dormant as germinate within 3 days (temporary cysts), while some others are resting cysts able to germinate for as long as 5 months after their formation. A study on the life cycle of $O$. cf. ovata conducted with northern Adriatic strains highlighted that resting cysts ger- minated in laboratory conditions at $25^{\circ} \mathrm{C}$, but not at $21^{\circ} \mathrm{C}$ (Accoroni et al., 2014). The presence of a temperature threshold affecting cyst germination in laboratory conditions would highlight that temperature could represent a key factor for Ostreopsis cf. ovata bloom onset also in natural environments.

\section{ROLE OF ENVIRONMENTAL PARAMETERS ON BLOOMS}

\section{Hydrodynamic conditions}

Several studies considered hydrodynamic condition as the main factor affecting Ostreopsis bloom trends, highlighting that higher abundances are observed in sheltered sites compared with exposed ones (Barone, 2007; Shears and Ross, 2009; Totti et al., 2010; Mabrouk et al., 2011). The abundances of benthic dinoflagellates are highly affected by wave action, since they are only loosely attached to the substrata and can be easily removed and re-suspended in the water column, although in literature we often found controversial data. Chang et al. (2000) suggested that $O$. cf. siamensis was more abundant on the northern New Zealand's eastern coast because it is a less energetic, more stable environment than the western one. This suggestion has been confirmed later by Shears and Ross (2009) that observed higher Ostreopsis siamensis abundances at sheltered $v s$ exposed locations. Vila et al. (2001), on the other hand, concluded that Ostreopsis sp. prefers 'moderately shaken' waters in the NW Mediterranean and Parsons and Preskitt (2007) observed higher abundance of $O$. cf. ovata on the windward coast of the island of Hawaii, whereas Ostreopsis sp.1 was more prevalent on the leeward coast.

Observations in the northern Adriatic Sea highlighted that 1) significantly higher abundances were observed in the sheltered sites compared with the exposed ones; 2) hydrodynamics may have an important effect on the temporal variability of bloom, because stormy events can result in a sudden decrease of cell abundances on the benthic substrata, with cell proliferation being re-established at high densities after some days of calm sea conditions (Totti et al., 2010; Accoroni et al., 2012a). Moreover, it has been highlighted that turbulence can affect $O$. cf. ovata growth rate and consequently its cell size (Accoroni et al., 2012b).

The effect of hydrodynamics has been separately tested for each bloom phase, i.e. initial (no more than $10^{2}$ cells $\mathrm{cm}^{-2}$ recorded over all substrata), proliferation (period of intense cell division, when $O$. cf. ovata rapidly increased abundances until reaching maximum peak) and decline phase (decrease in cell abundances and bloom decline), and it has been shown that cell abundances in sheltered sites were significantly higher than those in the 
exposed ones during the proliferation phase (Accoroni et al., 2012b). This result suggested that hydrodynamics affect $O$. cf. ovata abundances mainly during phases when the highest abundances are reached. In fact, a well-developed benthic mat (i.e., brownish pellicle loosely attached to benthic substrata) is produced only during the most intense proliferation period (Totti et al., 2010) and this structure is easily removed by effect of the hydrodynamic conditions. This result may explain why such effects linked to hydrodynamic conditions were not observed in those areas where high abundances were not reached and a mat did not develop, as observed in the Tyrrhenian Sea (Zingone, personal communication), and in Johnston Atoll (Pacific Ocean) (Richlen and Lobel, 2011).

\section{Water temperature}

Many authors suggested that Ostreopsis spp. need relatively high temperatures to proliferate, proposing that the global warming might have influenced Ostreopsis expansion in temperate areas such as the Mediterranean Sea (Hallegraeff, 2010; Granéli et al., 2011), but a more careful analysis of literature data shows that temperature role is not the same in all coastal areas around the world (Tab. 1). Ostreopsis blooms are summer events in temperate areas, although comparing the bloom trend in several Mediterranean areas it can be observed that peaks can occur from spring to autumn, with a certain inter-annual variability. In the northern Adriatic Sea, the peaks of the blooms occur generally in September-October (Monti et al., 2007; Totti et al., 2010; Accoroni et al., 2015a). On the contrary, in the Ligurian Sea highest cell abundances were mostly recorded in mid-summer (end of July) (Mangialajo et al., 2008). Vila et al. (2001) observed abundance peaks for Ostreopsis sp. in the north-western Mediterranean even early, in springtime. Also in the Aegean Sea, Spatharis et al. (2009) found $O$. cf. ovata being most abundant in May, contrarily to what observed in the same area by Aligizaki and Nikolaidis (2006) that reported peak abundances from midsummer to late fall.

Experimental studies about the response of Ostreopsis growth to temperature provide a possible explanation for the above different temporal trends observed in situ: Guerrini et al. (2010) and Pezzolesi et al. (2012) highlighted that $O$. cf. ovata strains from different Italian coasts (in the Tyrrhenian and Adriatic Seas) displayed different growth temperature optima that parallel with the in situ temperature values typical of the blooming period of the single strain. Scalco et al. (2012) observed that Mediterranean $O$. cf. ovata strains grew within a window of 18 $30^{\circ} \mathrm{C}$ with the best performances recorded between 22 and $26^{\circ} \mathrm{C}$, suggesting that $O$. cf. ovata is adapted to intermediate temperatures and day length conditions, such are those recorded in the natural environment at the beginning of summer and/or of autumn (Mangialajo et al., 2011). In
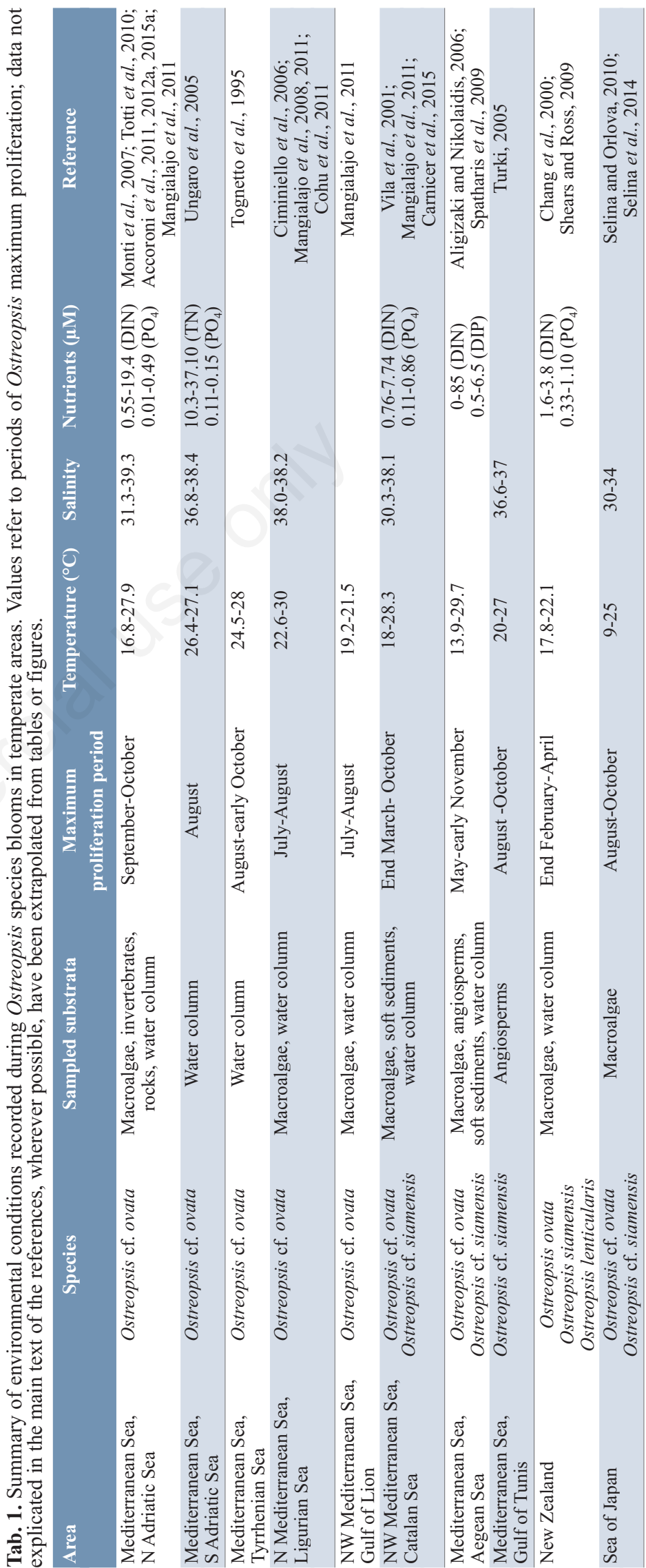
the same way, Tawong et al. (2015) observed that optimal and tolerable temperature conditions differ among Ostreopsis cf. ovata subclades: strains of $O$. cf. ovata Thailand subclade and $O$. cf. ovata South China Sea subclade showed the semi-optimal temperature ranges of 22.7$27.4^{\circ} \mathrm{C}$ and $27.9-30.8^{\circ} \mathrm{C}$, with optimal temperature of $25^{\circ} \mathrm{C}$ and $30^{\circ} \mathrm{C}$, respectively.

Although the reaching of the highest abundances of $\mathrm{Os}_{s-}$ treopsis is not in concomitance with the highest water temperature values in all areas, a temperature threshold would seem to be important to let the bloom start: a study conducted along the Conero Riviera (northern Adriatic Sea) showed that, although the bloom peak occurred in late summer (when temperatures ranged between 18.8 and $24^{\circ} \mathrm{C}$, decreasing from the seasonal maximum), the bloom onset was always observed at higher temperature $\left(25-28.6^{\circ} \mathrm{C}\right)$, suggesting that Ostreopsis needs to reach a fairly well fixed temperature threshold to start its bloom, probably in relation to the cyst germination that generally occurs at around $25^{\circ} \mathrm{C}$ (Accoroni et al., 2014). As in this area the bloom can persist until temperature values are much lower (14.4$17.5^{\circ} \mathrm{C}$ ) than that threshold, one would guess that once $O s$ treopsis cysts are germinated, its vegetative forms seem to actively proliferate even if temperature values decrease. This discrepancy between optimal temperature range for the cysts germination and the algal growth has been reported for the dinoflagellate Scrippsiella trochoidea as well by Binder and Anderson (1987) in experimental conditions. However, in the northern Adriatic Sea the bloom onset is often observed about 30 days after the reaching of the 25 ${ }^{\circ} \mathrm{C}$-temperature threshold, suggesting that other environmental factors, besides temperature, may affect the development of $O$. cf. ovata blooms. In this regard, $O$. cf. ovata blooms appear to be triggered by a combination of optimal temperature and available nutrients, where the temperature threshold plays a key role on the germination of $O$. cf. ovata cysts and an N:P ratio around the Redfield value is a necessary condition to allow cell proliferation.

\section{Role of salinity and nutrients}

Contrasting results are reported in the literature about the effect of salinity on the development of Ostreopsis blooms. Rhodes et al. (2000) observed that $O$. cf. siamensis had a preferred salinity range of 28-34 in cultures isolated from Northland (New Zealand). Salinity measured in the north-western Mediterranean Sea during the Ostreopsis spp. blooms showed values around 37-38 (Vila et al., 2001; Mangialajo et al., 2008) and similar salinity levels were measured in the Gulf of Trieste (northern Adriatic Sea) by Monti et al. (2007) and in the southern Adriatic Sea by Ungaro et al. (2005); in the Conero Riviera (northern Adriatic Sea) during the Ostreopsis blooms occurred from 2007 to 2012, salinity ranged in a much wider range, from 31.3 to 39.3 (Accoroni et al., 2015a).
Several authors suggested that benthic dinoflagellates proliferation is favoured by low salinity waters. In the Virgin Islands, abundance maxima of Ostreopsis were correlated with the period of maximal rainfall (Carlson and Tindall, 1985), and the same negative correlation with salinity has been found for $O$. ovata along the Hawaiian coasts (Parsons and Preskitt, 2007).

On the contrary, in the north-western coast of Cuba, in Catalonian and in French Mediterranean coasts, Delgado et al. (2006), Blanfuné et al., (2015) and Carnicer et al., (2015) suggested that low salinity values possibly hinder Ostreopsis spp. as they found conspicuously lower Ostreopsis abundances in sites more affected by river plumes (i.e., Jaimanitas River, Rhone River and Ebro Delta) than in the rest of the studied areas. No significant correlation between cell abundances and salinity values were found in the Gulf of Mexico for $O$. heptagona (Okolodkov et al., 2007) and in the Conero Riviera for $O$. cf. ovata (Accoroni et al., 2015a)

When the effect of salinity has been investigated in experimental conditions, it has been shown that such effect may be strain-specific: Tawong et al. (2015) showed that optimal and tolerable salinity conditions differed among Ostreopsis cf. ovata subclades as the optimal salinities for the O. cf. ovata Thailand and South China Sea subclades were 30 and 25, respectively. Pezzolesi et al. (2012) demonstrated that an Adriatic O. cf. ovata strain cultured at salinity ranging from 26 to 40 showed that although the lowest growth rates were observed at the lowest salinity, growth rates did not significantly differ in different salinity conditions.

Indeed, the relationships between algal blooms in the field and salinity are more complicated, and other factors, such as nutrient levels (which are typically associated to low salinity waters) have to be considered. Recent studies have provided increasing evidence of a link between the nutrient enrichment of coastal waters (anthropogenic eutrophication) and harmful algal events (Glibert and Burkholder, 2006; Glibert et al., 2010). However, there is very limited information on the relationships between nutrient concentrations and the occurrence of Ostreopsis blooms (Tab. 1). Vila et al. (2001) and Cohu et al. (2011) in northwestern Mediterranean Sea and Shears and Ross (2009) in north-eastern New Zealand did not find any relation between epiphytic $O$. cf. ovata abundance and nutrients, while Parsons and Preskitt (2007) found that Ostreopsis sp.1 abundance was positively correlated with nutrient concentrations in the waters surrounding Hawaii. In the Conero Riviera (northern Adriatic Sea), although no clear relationship was found between nutrient concentrations and $O$. cf. ovata abundances, it was observed that in the bloom onset period, $\mathrm{PO}_{4}$ concentrations were significantly higher than in the rest of the study period. Interestingly, the following bloom development is maintained in a con- 
dition of elevated $\mathrm{N}:$ P ratios, suggesting that such blooms may be initiated at low N:P levels (possibly stimulated by a 'flush' of nutrients or organic materials) that may allow the newly germinating cells to increase growth rate while other adaptive mechanisms (e.g., metabolic dissipatory strategies, allelopathic and mixotrophic interactions), would enable the maintenance of blooms at less than maximal growth rates and at not-optimal N:P ratios (Accoroni et al., 2015a). A decrease in $\mathrm{N}: \mathrm{P}$ ratio values has previously been associated with the onset of a number of planktonic dinoflagellate blooms as well (Hodgkiss and Ho, 1997; Zhang and $\mathrm{Hu}, 2011$; Glibert et al., 2012). In this regard, experimental studies conducted on different Adriatic $O$. cf. ovata strains showed that the depletion of $\mathrm{P}$ was proportionately more rapid than that of $\mathrm{N}$, highlighting the strong P demand of this dinoflagellate (Vanucci et al., 2012b; Pezzolesi et al., 2014).

Moreover, further studies are needed to clarify the trophic behaviour of Ostreopsis spp., considering that for these species also mixotrophy was hypothesized (Barone, 2007; Burkholder et al., 2008), which may play an important role in Ostreopsis development, as already observed in other potentially toxic microalgae (Cucchiari et al., 2008; Heisler et al., 2008).

\section{Depth}

The role of depth on Ostreopsis abundances along the Conero Riviera (northern Adriatic Sea) was investigated in 2007 (Totti et al., 2010) in target sites where samples were collected at depths comprised between 0.5 and 10 m. O. cf. ovata abundances showed a significant decrease with depth, in agreement with what observed by Richlen and Lobel (2011) and Cohu and Lemée (2012), suggesting a potential effect of light intensity. This may explain why Ostreopsis blooms mainly develop in shallow waters. However, such effect has not been observed in shallow sites affected by high hydrodynamics, such as on the fringing reefs of the higher infralittoral shelf, where $O$. cf. ovata abundances were lower than those recorded immediately deeper, due to the hydrodynamic effect of wave actions (Totti et al., 2010).

As previously suggested, the role of depth may be related to light availability, although there are conflicting data about the relationship between light intensity and $O s-$ treopsis growth in experimental conditions. Morton et al. (1992) reported that $O$. cf. siamensis and $O$. heptagona isolated from the Florida Keys displayed maximal growth at approximately $200 \mu \mathrm{mol}$ photons $\mathrm{m}^{-2} \mathrm{~s}^{-1}$ and did not grow rapidly at over $240 \mu \mathrm{mol}$ photons $\mathrm{m}^{-2} \mathrm{~s}^{-1}$ (i.e., $>10 \%$ full sun light). Scalco et al. (2012), analysing the growth performance of some Italian $O$. cf ovata strains, observed that this species grew better at relatively low photon flux density (50 instead of $200 \mu \mathrm{mol}$ photons $\mathrm{m}^{-2} \mathrm{~s}^{-1}$ ). Yamaguchi et al. (2014) observed that Ostreopsis sp. from
Japan grew proportionally when light intensity was increased from 49.5 to $199 \mu \mathrm{mol}$ photons $\mathrm{m}^{-2} \mathrm{~s}^{-1}$, but its growth appeared to be inhibited slightly at $>263 \mu \mathrm{mol}$ photons $\mathrm{m}^{-2} \mathrm{~s}^{-1}$. Heil et al. (1993) observed that $O$. cf. siamensis cultured in spinner flasks would stay planktonic when light intensities are maintained low $(25 \mu \mathrm{mol}$ photons $\mathrm{m}^{-2} \mathrm{~s}^{-1}$ ), but would produce mucus and settle at the bottom at higher light intensities ( $75 \mu$ mol photons $\mathrm{m}^{-2} \mathrm{~s}$ $\left.{ }^{1}\right)$. This has been interpreted as a protective measure to shade the cells. Therefore, in experimental conditions $O s$ treopsis sp. seems to suffer too high light intensities, therefore being exposed to potentially detrimental consequences of photodamaging.

In field conditions, there are only few data about the relationship between Ostreopsis abundances and light intensity, which, moreover, seem to disagree with the experimental evidences described above. A study carried out along several Italian coastal areas affected by Ostreopsis blooms showed that during the blooms, the values of light intensity at depth of Ostreopsis sampling were quite high, up to $1800 \mu \mathrm{mol}$ photons $\mathrm{m}^{-2} \mathrm{~s}^{-1}$ (ISPRA, 2012). However, it is known that light availability amidst macroalgal vegetation is generally low (Raniello et al., 2004), and Ballantine et al. (1988) suggested that Ostreopsis cells can migrate to shaded areas of the algal host thallus to escape high light levels.

Anyway, further studies are required to clarify the real role of light intensity in the bloom dynamics of Ostreopsis.

\section{Substratum}

Ostreopsis has often been indicated to be preferentially epiphytic on macroalgae (Bomber et al., 1989; Vila et al., 2001), although it has been recorded on a variety of other substrata (Table 1), including marine angiosperms (Turki, 2005; Aligizaki and Nikolaidis, 2006; Turki et al., 2006; Battocchi et al., 2010; Mabrouk et al., 2012), rocks (Bottalico et al., 2002; Totti et al., 2010; Accoroni et al., 2011), coral rubble (Norris et al., 1985), soft sediments (Vila et al., 2001; Aligizaki and Nikolaidis, 2006), and invertebrates (Bianco et al., 2007; Totti et al., 2010). They also can be found as free-living in the plankton (Faust and Morton, 1995; Tognetto et al., 1995; Chang et al., 2000; Totti et al., 2010; Accoroni et al., 2011).

The possibility of Ostreopsis to colonize a variety of substrata, living either as epiphytic, epilithic, or epizoic, indicates that this species is not an obligate epiphyte.

A number of studies underlined the importance of host thallus architecture (Lobel et al., 1988; Bomber et al., 1989). Vila et al. (2001) observed that three-dimensional flexible thalli are more suitable for the growth of Ostreopsis spp. It has been suggested that the higher abundances found in branched than in flattened thalli, might be explained by a different response of such thallus morphotypes to the wave action (Totti et al., 2010). 
Indeed, the relationships between Ostreopsis and macrophytes are more complicated. In studies carried out on natural populations of $O$. cf. ovata, significantly higher abundances were reported on pebbles than on macroalgae (Totti et al., 2010; Accoroni et al., 2011), suggesting that living substrata allow lower concentration of epibionts than any other substrate, probably due to the production of some hypothetical allelopathic compounds (Jin and Dong, 2003). In this regard, a study conducted to assess any possible allelopathic interactions between Ostreopsis cf. ovata and macroalgae showed that all the investigated seaweeds [Dictyota dichotoma (brown alga), Rhodymenia pseudopalmata (red alga) and Ulva rigida (green alga)] exerted negative effects toward the benthic dinoflagellate, with the highest inhibitory effect observed in $D$. dichotoma and the lowest in R. pseudopalmata (Accoroni et al., 2015b).

\section{UNRESOLVED ISSUES}

Despite the number of studies on Ostreopsis biology, ecology and toxin production and actions, several aspects about the environmental concerns associated with this genus remain still unclear. Regarding the action mechanism of the implicated toxins, almost all studies refer to the commercial PITX standard, while a more accurate analysis should be addressed on both effects and action mechanism of all toxins produced by Ostreopsis species. Moreover, among the vectors of Ostreopsis intoxication i.e., marine aerosol, direct contact and per os ingestion, the latter needs certainly further studies given its possible implications on human health almost unknown in temperate areas nowadays.

Numerous studies have highlighted the influence of environmental factors on bloom dynamics of Ostreopsis and the complexity of conditions leading to blooms of this dinoflagellate is becoming clearer but not totally understood. Although the mechanisms for bloom onset seems clarified, those driving both bloom development and decline are still far from being understood, and other both abiotic and biotic factors, such as the interactions with other organisms and the ability to use organic forms of nutrients, should be investigated. Actually, several HAB genera have been shown to use organic forms of nutrients for their nutritional demands (Cucchiari et al., 2008; Heisler et al., 2008) and a mixotrophic behavior has been hypothesized in Ostreopsis (Barone, 2007; Burkholder et al., 2008; Pinna et al., 2015). Effects of biotic interactions on Ostreopsis should be considered as well and only few studies have been carried out on bacteria (Vanucci et al., 2012a), diatoms (Pichierri et al 2015) and macroalgae (Accoroni et al., 2015b). In this regard, the role of viruses, bacteria and parasites in both cysts formation and bloom termination have been recognized in several microalgae
(Nagasaki et al., 1994; Nagasaki et al., 2000; Tarutani et al., 2001; Mizumoto et al., 2008; Garcés et al., 2013) and should be studied in Ostreopsis bloom dynamics as well.

\section{ACKNOWLEDGMENTS}

This study was partially supported by ISPRA-Italian Ministry of the Environment, MURST (PRIN 2007), and ENPI CBCMED M3-HABs project.

\section{REFERENCES}

Accoroni S, Romagnoli T, Colombo F, Pennesi C, Di Camillo CG, Marini M, Battocchi C, Ciminiello P, Dell'Aversano C, Dello Iacovo E, Fattorusso E, Tartaglione L, Penna A, Totti C, 2011. Ostreopsis cf. ovata bloom in the northern Adriatic Sea during summer 2009: ecology, molecular characterization and toxin profile. Mar. Pollut. Bull. 62:2512-2519.

Accoroni S, Colombo F, Pichierri S, Romagnoli T, Marini M, Battocchi C, Penna A, Totti C, 2012a. Ecology of Ostreopsis cf. ovata blooms in the northwestern Adriatic Sea. Cryptogam. Algol. 33:191-198.

Accoroni S, Romagnoli T, Pichierri S, Colombo F, Totti C, 2012b. Morphometric analysis of Ostreopsis cf. ovata cells in relation to environmental conditions and bloom phases. Harmful Algae 19:15-22.

Accoroni S, Romagnoli T, Pichierri S, Totti C, 2014. New insights on the life cycle stages of the toxic benthic dinoflagellate Ostreopsis cf. ovata. Harmful Algae 34:7-16.

Accoroni S, Glibert PM, Pichierri S, Romagnoli T, Marini M, Totti C, 2015a. A conceptual model of annual Ostreopsis cf. ovata blooms in the northern Adriatic Sea based on the synergic effects of hydrodynamics, temperature, and the N:P ratio of water column nutrients. Harmful Algae 45:14-25.

Accoroni S, Percopo I, Cerino F, Romagnoli T, Pichierri S, Perrone $\mathrm{C}$, Totti $\mathrm{C}, 2015 \mathrm{~b}$. Allelopathic interactions between the HAB dinoflagellate Ostreopsis cf. ovata and macroalgae. Harmful Algae 49:147-155.

Adachi M, Ikegami T, Yamaguchi H, 2008. The genus Ostreopsis in the coastal regions in Tosa Bay, southern part of Japan, p. 1. In: Proc. 13th Int. Conf. on Harmful Algae, Hong Kong.

Alcala AC, Alcala LC, Garth JS, Yasumura D, Yasumoto T, 1988. Human fatality due to ingestion of the crab Demania reynaudii that contained a palytoxin-like toxin. Toxicon 26:105-107.

Aligizaki K, Nikolaidis G, 2006. The presence of the potentially toxic genera Ostreopsis and Coolia (Dinophyceae) in the north Aegean sea, Greece. Harmful Algae 5:717-730.

Aligizaki K, Katikou P, Nikolaidis G, Panou A, 2008. First episode of shellfish contamination by palytoxin-like compounds from Ostreopsis species (Aegean Sea, Greece). Toxicon 51:418-427.

Amorim A, Veloso V, Penna A, 2010. First detection of Ostreopsis cf. siamensis in Portuguese coastal waters. Harmful Algae News 42:6-7.

Anderson DM, Taylor CD, Armbrust EV, 1987. The effects of darkness and anaerobiosis on dinoflagellate cyst germination. Limnol. Oceanogr. 32:340-351. 
Artigas P, Gadsby DC, 2003. Na+/K+-pump ligands modulate gating of palytoxin-induced ion channels. P. Natl. Acad. Sci. USA 100:501-505.

Ballantine DL, Bardales AT, Tosteson TR, Durst HD, 1985. Seasonal abundance of Gambierdiscus toxicus and Ostreopsis $s p$. in coastal waters of southwest Puerto Rico, p. 417-422. In: Proc. 5th Int. Coral Reef Congr., Tahiti.

Ballantine DL, Tosteson TR, Bardales AT, 1988. Population dynamics and toxicity of natural populations of benthic dinoflagellates in southwestern Puerto Rico. J. Exp. Mar. Biol. Ecol. 119:201-212.

Barone R, 2007. Behavioural trait of Ostreopsis ovata (Dinophyceae) in Mediterranean rock pools: the spider's strategy. Harmful Algae News 33:1-3.

Battocchi C, Totti C, Vila M, Masó M, Capellacci S, Accoroni S, Reñé A, Scardi M, Penna A, 2010. Monitoring toxic microalgae Ostreopsis (dinoflagellate) species in coastal waters of the Mediterranean Sea using molecular PCR-based assay combined with light microscopy. Mar. Pollut. Bull. 60:1074-1084.

Bellocci M, Sala GL, Prandi S, 2011. The cytolytic and cytotoxic activities of palytoxin. Toxicon 57:449-459.

Bennouna A, El Attar J, Abouabdellah R, Palma S, Penna A, Moita T, 2010. First records of Ostreopsis cf. siamensis in Moroccan Atlantic upwelling waters. Harmful Algae News 42:1-3.

Bianco I, Sangiorgi V, Penna A, Guerrini F, Pistocchi R, Zaottini E, Congestri R, 2007. Ostreopsis ovata in benthic aggregates along the Latium Coast (middle Tyrrhenian Sea), p. 29 (abstract). In: Proc. Int. Symp. on Algal Toxins, Trieste, Italy.

Binder BJ, Anderson DM, 1987. Physiological and environmental control of germination in Scrippsiella trochoidea (dinophyceae) resting cysts. J. Phycol. 23:99-107.

Blanfuné A, Boudouresque C, Grossel H, Thibaut T, 2015. Distribution and abundance of Ostreopsis spp. and associated species (Dinophyceae) in the northwestern Mediterranean: the region and the macroalgal substrate matter Environ. Sci. Pollut. Res.22:12332-12346.

Bomber JW, Aikman KE, 1989. The ciguatera dinoflagellates. Biol. Oceanogr. 6:291-311.

Bomber JW, Rubio MG, Norris DR, 1989. Epiphytism of dinoflagellates associated with the disease ciguatera: substrate specificity and nutrition. Phycologia 28:360-368.

Bottalico A, Micella P, Feliciti GP, 2002. [Fioritura di Ostreopsis sp. (Dinophyta) nel porto di Otranto].[Article in Italian]. In: Proc. Riunione Scientifica Annuale del Gruppo di Lavoro per l'Algologia - Società Botanica Italiana, Chioggia, Italy.

Bravo I, Vila M, Casabianca S, Rodriguez F, Rial P, Riobó P, Penna A, 2012. Life cycle stages of the benthic palytoxinproducing dinoflagellate Ostreopsis cf. ovata (Dinophyceae). Harmful Algae 18:24-34.

Brescianini C, Grillo C, Melchiorre N, Bertolotto R, Ferrari A, Vivaldi B, Icardi G, Gramaccioni L, Funari E, Scardala S, 2006. Ostreopsis ovata algal blooms affecting human health in Genova, Italy, 2005 and 2006. Euro Surveill. 11:E060907.3.

Brissard C, Hervé F, Sibat M, Séchet V, Hess P, Amzil Z, Herrenknecht $\mathrm{C}, 2015$. Characterization of ovatoxin-h, a new ovatoxin analog, and evaluation of chromatographic columns for ovatoxin analysis and purification. J. Chromatogr. A 1388:87-101.

Burkholder JM, Glibert PM, Skelton HM, 2008. Mixotrophy, a major mode of nutrition for harmful algal species in eutrophic waters. Harmful Algae 8:77-93.

Carella F, Sardo A, Mangoni O, Di Cioccio D, Urciuolo G, De Vico G, Zingone A, 2015. Quantitative histopathology of the Mediterranean mussel (Mytilus galloprovincialis L.) exposed to the harmful dinoflagellate Ostreopsis cf. ovata. J. Invertebr. Pathol. 127:130-140.

Carlson RD, Tindall DR, 1985. Distribution and periodicity of toxic dinoflagellates in the Virgin Islands, p. 171-176. In: D.M. Anderson, A.W. White and D.G. Baden (eds.), Toxic dinoflagellates. Elsevier.

Carnicer O, Guallar C, Andree KB, Diogène J, Fernández-Tejedor M, 2015. Ostreopsis cf. ovata dynamics in the NW Mediterranean Sea in relation to biotic and abiotic factors. Environ. Res. 143(Pt B):89-99.

Casabianca S, Casabianca A, Riobó P, Franco JM, Vila M, Penna A, 2013. Quantification of the toxic dinoflagellate Ostreopsis spp. by qPCR assay in marine aerosol. Environ. Sci. Technol. 47:3788-3795.

Casabianca S, Perini F, Casabianca A, Battocchi C, Giussani V, Chiantore M, Penna A, 2014. Monitoring toxic Ostreopsis cf. ovata in recreational waters using a qPCR based assay. Mar. Pollut. Bull. 88:102-109.

Chang FH, Shimizu Y, Hay B, Stewart R, Mackay G, Tasker R, 2000. Three recently recorded Ostreopsis spp. (Dinophyceae) in New Zealand: temporal and regional distribution in the upper North Island from 1995 to 1997. New Zeal. J. Mar. Fresh. 34:29-39.

Ciminiello P, Dell'Aversano C, Dello Iacovo E, Fattorusso E, Forino M, Grauso L, Tartaglione L, Guerrini F, Pezzolesi L, Pistocchi R, Vanucci S, 2012a. Isolation and structure elucidation of ovatoxin-a, the major toxin produced by Ostreopsis ovata. J. Am. Chem. Soc. 134:1869-1875.

Ciminiello P, Dell'Aversano C, Dello Iacovo E, Fattorusso E, Forino M, Tartaglione L, Battocchi C, Crinelli R, Carloni E, Magnani M, Penna A, 2012b. Unique toxin profile of a Mediterranean Ostreopsis cf. ovata strain: HR LC-MSn characterization of ovatoxin-f, a new palytoxin congener. Chem. Res. Toxicol. 25:1243-1252.

Ciminiello P, Dell'Aversano C, Dello Iacovo E, Fattorusso E, Forino M, Tartaglione L, Benedettini G, Onorari M, Serena F, Battocchi C, Casabianca S, Penna A, 2014. First finding of Ostreopsis cf. ovata toxins in marine aerosols. Environ. Sci. Technol. 48:3532-3540.

Ciminiello P, Dell'Aversano C, Fattorusso E, Forino M, Magno GS, Tartaglione L, Grillo C, Melchiorre N, 2006. The Genoa 2005 outbreak. Determination of putative palytoxin in Mediterranean Ostreopsis ovata by a new liquid chromatography tandem mass spectrometry method. Anal. Chem. 78:6153-6159.

Ciminiello P, Dell'Aversano C, Fattorusso E, Forino M, Tartaglione L, Grillo C, Melchiorre N, 2008. Putative palytoxin and its new analogue, ovatoxin-a, in Ostreopsis ovata collected along the Ligurian coasts during the 2006 toxic outbreak. J. Am. Soc. Mass Spectrom. 19:111-120.

Ciminiello P, Dell'Aversano C, Dello Iacovo E, Fattorusso E, Forino M, Tartaglione L, Yasumoto T, Battocchi C, Giacobbe M, Amorim A, Penna A, 2013. Investigation of toxin profile of Mediterranean and Atlantic strains of Ostreopsis cf. siamensis (Dinophyceae) by liquid chromatography-high 
resolution mass spectrometry. Harmful Algae 23:19-27.

Cohu S, Lemée R, 2012. Vertical distribution of the toxic epibenthic dinoflagellates Ostreopsis cf. ovata, Prorocentrum lima and Coolia monotis in the NW Mediterranean Sea. Cah. Biol. Mar. 53:373-380.

Cohu S, Thibaut T, Mangialajo L, Labat J-P, Passafiume O, Blanfuné A, Simon N, Cottalorda J-M, Lemée R, 2011. Occurrence of the toxic dinoflagellate Ostreopsis cf. ovata in relation with environmental factors in Monaco (NW Mediterranean). Mar. Pollut. Bull. 62:2681-2691.

Cucchiari E, Guerrini F, Penna A, Totti C, Pistocchi R, 2008. Effect of salinity, temperature, organic and inorganic nutrients on growth of cultured Fibrocapsa japonica (Raphidophyceae) from the northern Adriatic Sea. Harmful Algae 7:405-414.

Del Favero G, Sosa S, Pelin M, D'Orlando E, Florio C, Lorenzon P, Poli M, Tubaro A, 2012. Sanitary problems related to the presence of Ostreopsis spp. in the Mediterranean Sea: a multidisciplinary scientific approach. Ann. Ist. Super. Sanità 48:407-414.

Delgado G, Lechuga-Deveze CH, Popowski G, Troccoli L, Salinas CA, 2006. Epiphytic dinoflagellates associated with ciguatera in the northwestern coast of Cuba. Rev. Biol. Trop. 54:299-310.

Di Turi L, Lo Caputo S, Marzano MC, Pastorelli AM, Pompei M, Rositani L, Ungaro N, 2003. [Sulla presenza di Ostreopsidaceae (Dinophyceae) lungo il litorale barese].[Article in Italian]. Biol. Mar. Mediterr. 10(2):675-678.

Durando P, Ansaldi F, Oreste P, Moscatelli P, Gasparini LM, Icardi G, Collaborative Group for the Ligurian Syndromic Algal Surveillance, 2007. Ostreopsis ovata and human health: epidemiological and clinical features of respiratory syndrome outbreaks from a two-year sindromi surveillance, 2005-06, in north-west Italy. Euro Surveill. 12:E070607.1 - Erratum in Euro Surveill. 2007;12:following E070705.4.

EFSA, 2009. Marine biotoxins in shellfish - palytoxin group. Opinion of the scientific panel on contaminants in the food chain. EFSA J. 7:1393-1430.

Etheridge SM, Roesler CS, 2005. Effects of temperature, irradiance, and salinity on photosynthesis, growth rates, total toxicity, and toxin composition for Alexandrium fundyense isolates from the Gulf of Maine and Bay of Fundy. DeepSea. Res. Pt. II 52:2491-2500.

Faimali M, Giussani V, Piazza V, Garaventa F, Corrà C, Asnaghi V, Privitera D, Gallus L, Cattaneo-Vietti R, Mangialajo L, Chiantore M, 2012. Toxic effects of harmful benthic dinoflagellate Ostreopsis ovata on invertebrate and vertebrate marine organisms. Mar. Environ. Res. 76:97-107.

Faust MA, 1992. Observations on the morphology and sexual reproduction of Coolia monotis (Dinophyceae). J. Phycol. 28:94-104.

Faust MA, 1999. Three new Ostreopsis species (Dinophyceae): $O$. marinus sp. nov., O. belizeanus sp. nov., and $O$. carribeanus sp. nov. Phycologia 38:92-99.

Faust MA, Morton SL, 1995. Morphology and ecology of the marine dinoflagellate Ostreopsis labens sp. nov. (Dinophyceae). J. Phycol. 31:456-463.

Fujiki H, Suganuma M, 2009. Carcinogenic aspects of protein phosphatase 1 and 2A inhibitors, p. 221-254. In: N. Fusetani and W. Kem (eds.), Marine toxins as research tools. Springer.
Fujiki H, Suganuma M, Nakayasu M, Hakii H, Horiuchi T, Takayama S, Sugimura T, 1986. Palytoxin is a non-12-Otetradecanoylphorbol-13-acetate type tumor promoter in twostage mouse skin carcinogenesis. Carcinogenesis 7:707-710.

Fukui M, Murata M, Inoue A, Gawel M, Yasumoto T, 1987. Occurrence of palytoxin in the trigger fish Melichtys vidua. Toxicon 25:1121-1124.

Fukuyo Y, 1981. Taxonomical study on benthic dinoflagellates collected in coral reefs. Bull. Japan. Soc. Sci. Fish. 47: 967-978.

Gallitelli M, Ungaro N, Addante LM, Silver NG, Sabba C, 2005. Respiratory illness as a reaction to tropical algal blooms occurring in a temperate climate. JAMA-J. Am. Med. Assoc. 293:2599-2600.

Garcés E, Alacid E, Bravo I, Fraga S, Figueroa RI, 2013. Parvilucifera sinerae (Alveolata, Myzozoa) is a generalist parasitoid of dinoflagellates. Protist 164:245-260.

García-Altares M, Tartaglione L, Dell'Aversano C, Carnicer O, de la Iglesia $P$, Forino M, Diogène J, Ciminiello $P, 2015$. The novel ovatoxin-g and isobaric palytoxin (so far referred to as putative palytoxin) from Ostreopsis cf. ovata (NW Mediterranean Sea): structural insights by LC-high resolution MSn. Anal. Bioanal. Chem. 407:1191-1204.

Gleibs S, Mebs D, Werding B, 1995. Studies on the origin and distribution of palytoxin in a Caribbean coral reef. Toxicon 33:1531-1537.

Glibert PM, Burkholder JM, 2006. The complex relationships between increases in fertilization of the earth, coastal eutrophication and proliferation of harmful algal blooms, $p$. 341-354. In: E. Granéli and J.T. Turner (eds.), Ecology of harmful algae. Springer.

Glibert PM, Allen JI, Bouwman AF, Brown CW, Flynn KJ, Lewitus AJ, Madden CJ, 2010. Modeling of HABs and eutrophication Status, advances, challenges. J. Mar. Syst. 83:262-275.

Glibert PM, Burkholder JM, Kana TM, 2012. Recent insights about relationships between nutrient availability, forms, and stoichiometry, and the distribution, ecophysiology, and food web effects of pelagic and benthic Prorocentrum species. Harmful Algae 14:231-259.

Gorbi S, Bocchetti R, Binelli A, Bacchiocchi S, Orletti R, Nanetti L, Raffaelli F, Vignini A, Accoroni S, Totti C, Regoli F, 2012. Biological effects of palytoxin-like compounds from Ostreopsis cf. ovata: A multibiomarkers approach with mussels Mytilus galloprovincialis. Chemosphere 89:623-632.

Gorbi S, Avio GC, Benedetti M, Totti C, Accoroni S, Pichierri S, Bacchiocchi S, Orletti R, Graziosi T, Regoli F, 2013. Effects of harmful dinoflagellate Ostreopsis cf. ovata exposure on immunological, histological and oxidative responses of mussels Mytilus galloprovincialis. Fish Shellfish Immunol. 35:941-950.

Granéli E, Vidyarathna NK, Funari E, Cumaranatunga PRT, Scenati R, 2011. Can increases in temperature stimulate blooms of the toxic benthic dinoflagellate Ostreopsis ovata? Harmful Algae 10:165-172.

Guerrini F, Pezzolesi L, Feller A, Riccardi M, Ciminiello P, Dell'Aversano C, Tartaglione L, Dello Iacovo E, Fattorusso E, Forino M, Pistocchi R, 2010. Comparative growth and toxin profile of cultured Ostreopsis ovata from the Tyrrhenian and Adriatic Seas. Toxicon 55:211-220. 
Habermann E, Ahnert-Hilger G, Chhatwal GS, Beress L, 1981. Delayed haemolytic action of palytoxin. General characteristics. Biochim. Biophys. Acta 649:481-486.

Hallegraeff GM, 2010. Ocean climate change, phytoplankton community responses, and harmful algal blooms: A formidable predictive challenge. J. Phycol. 46:220-235.

Hansen G, Turquet J, Quod JP, Ten-Hage L, Lugomela C, Kyewalyanga M, Hurbungs M, Wawiye P, Ogongo B, Tunje S, Rakotoarinjanahary H, 2001. Potentially harmful algae of the western Indian Ocean: a guide based on a preliminary survey. I.O.C., Manuals and Guides 41. Intergovernmental Oceanographic Commission of UNESCO.

Heil CA, Maranda L, Shimizu Y, 1993. Mucus-associated dinoflagellates: Large scale culturing and estimation of growth rate, p. 501-506. In: T.J. Smayda and H. Shimizu (eds), Toxic phytoplankton blooms in the sea. Elsevier.

Heisler J, Glibert PM, Burkholder JM, Anderson DM, Cochlan W, Dennison WC, Dortch Q, Gobler CJ, Heil CA, Humphries E, Lewitus A, Magnien R, Marshall HG, Sellner K, Stockwell DA, Stoecker DK, Suddleson M, 2008. Eutrophication and harmful algal blooms: a scientific consensus. Harmful Algae 8:3-13.

Hodgkiss IJ, Ho KC, 1997. Are changes in N:P ratios in coastal waters the key to increased red tide blooms? Hydrobiologia 352:141-147.

Holmes MJ, Gillespie NC, Lewis RJ, 1988. Toxicity and morphology of Ostreopsis $\mathrm{cf}$. siamensis cultured from a ciguatera endemic region of Queensland, Australia, pp. 49-54. In: J.H. Choat, D. Barnes, M.A. Borowitzka, J.C. Coll, P.J. Davies, P. Flood, B.G. Hatcher, D. Hopley, P.A. Hutchings, D. Kinsey, G.R. Orme, M. Pichon, P.F. Sale, P. Sammarco, C.C. Wallace, C. Wilkinson, E. Wolanski and O. Bellwood (eds.), Proc. 6th Int. Coral Reef Symp., Townsville, Australia.

Honsell G, De Bortoli M, Boscolo S, Dell'Aversano C, Battocchi C, Fontanive G, Penna A, Berti F, Sosa S, Yasumoto T, Ciminiello P, Poli M, Tubaro A, 2011. Harmful dinoflagellate Ostreopsis cf. ovata Fukuyo: detection of ovatoxins in field samples and cell immunolocalization using antipalytoxin antibodies. Environ. Sci. Technol. 45:7051-7059.

Hoppenrath M, Murray SA, Chomérat N, Horiguchi T, 2014. Marine benthic dinoflagellates - unveiling their worldwide biodiversity. Schweizerbart Science, Stuttgart: 276 pp.

Illoul H, Hernandez FR, Vila M, Adjas N, Younes AA, Bournissa M, Koroghli A, Marouf N, Rabia S, Ameur FLK, 2012. The genus Ostreopsis along the Algerian coastal waters (SW Mediterranean Sea) associated with a human respiratory intoxication episode. Cryptogam. Algol. 33:209-216.

Ismael A, Halim Y, 2012. Potentially harmful Ostreopsis spp. In the coastal waters of Alexandria-Egypt. Mediterr. Mar. Sci. 13:208-212.

ISPRA, 2012. [Ostreopsis cf. ovata lungo le coste italiane: monitoraggio 2011].[Report in Italian]. Rapporti 173/2012. ISPRA. Available from: http://www.isprambiente.gov.it/en/ publications/reports/ostreopsis-ovata-along-the-italian-coastmonitoring-2011?set_language $=$ en

Jin Q, Dong S, 2003. Comparative studies on the allelopathic effects of two different strains of Ulva pertusa on Heterosigma akashiwo and Alexandrium tamarense. J. Exp. Mar. Biol. Ecol. 293:41-55.

Johansson N, Granéli E, 1999a. Cell density, chemical compo- sition and toxicity of Chrysochromulina polylepis (Haptophyta) in relation to different N:P supply ratios. Mar. Biol. 135:209-217.

Johansson N, Granéli E, 1999b. Influence of different nutrient conditions on cell density, chemical composition and toxicity of Prymnesium parvum (Haptophyta) in semi-continuous cultures. J. Exp. Mar. Biol. Ecol. 239:243-258.

Kermarec F, Dor F, Armengaud A, Charlet F, Kantin R, Sauzade D, De Haro L, 2008. [Les risques sanitaires liés à la présence d'Ostreopsis ovata dans les eaux de baignade ou d'activités nautiques].[Article in French]. Environ Risque Sante 7:357-363.

Kim HS, Yih W, Kim JH, Myung G, Jeong HJ, 2011. Abundance of epiphytic dinoflagellates from coastal waters off Jeju Island, Korea During Autumn 2009. Ocean Sci. J. 46:205-209.

Kodama AM, Hokama Y, Yasumoto T, Fukui M, Manea SJ, Sutherland N, 1989. Clinical and laboratory findings implicating palytoxin as cause of ciguatera poisoning due to $D e$ capterus macrosoma (mackerel). Toxicon 27:1051-1053.

Laza-Martinez A, Orive E, Miguel I, 2011. Morphological and genetic characterization of benthic dinoflagellates of the genera Coolia, Ostreopsis and Prorocentrum from the southeastern Bay of Biscay. Eur. J. Phycol. 46:45-65.

Leaw C-P, Lim PT, Ahmad A, Usup G, 2001. Genetic diversity of Ostreopsis ovata (Dinophyceae) from Malaysia. Mar. Biotechnol. 3:246-255.

Lenoir S, Ten-Hage L, Turquet J, Quod JP, Bernard C, Hennion MC, 2004. First evidence of palytoxin analogues from an Ostreopsis mascarenensis (Dinophyceae) benthic bloom in Southwestern Indian Ocean. J. Phycol. 40:1042-1051.

Litaker RW, Vandersea MW, Kibler SR, Madden VJ, Noga EJ, Tester PA, 2002. Life cycle of the heterotrophic dinoflagellate Pfiesteria piscicida (Dinophyceae). J. Phycol. 38:442-463.

Lobel PS, Anderson DM, Durand-Clement M, 1988. Assessment of ciguatera dinoflagellate populations - sample variability and algal substrate selection. Biol. Bull. 175:94-101.

Mabrouk L, Hamza A, Brahim MB, Bradai MN, 2011. Temporal and depth distribution of microepiphytes on Posidonia oceanica (L.) Delile leaves in a meadow off Tunisia. Mar. Ecol. 32:148-161.

Mabrouk L, Hamza A, Mahfoudi M, Bradai MN, 2012. Spatial and temporal variations of epiphytic Ostreopsis siamensis on Posidonia oceanica (L.) Delile leaves in Mahdia (Tunisia). Cah. Biol. Mar. 53:419-427.

Mangialajo L, Bertolotto R, Cattaneo-Vietti R, Chiantore M, Grillo C, Lemée R, Melchiorre N, Moretto P, Povero P, Ruggieri N, 2008. The toxic benthic dinoflagellate Ostreopsis ovata: Quantification of proliferation along the coastline of Genoa, Italy. Mar. Pollut. Bull. 56:1209-1214.

Mangialajo L, Ganzin N, Accoroni S, Asnaghi V, Blanfuné A, Cabrini M, Cattaneo-Vietti R, Chavanon F, Chiantore M, Cohu S, Costa E, Fornasaro D, Grossel H, Marco-Miralles F, Masó M, Reñé A, Rossi AM, Sala MM, Thibaut T, Totti C, Vila M, Lemée R, 2011. Trends in Ostreopsis proliferation along the Northern Mediterranean coasts. Toxicon 57:408-420.

Mercado JA, Rivera-Rentas AL, Gonzalez I, Tosteson TR, Molgo J, Escalona de Motta G, 1994. Neuro-and myo-toxicity of extracts from the benthic dinoflagellate Ostreopsis lenticularis is sensitive to $\mu$-conotoxin. Soc. Neurosci. Abstracts 20:718. 
Meunier FA, Mercado JA, Molgó J, Tosteson TR, Escalona de Motta G, 1997. Selective depolarization of the muscle membrane in frog nerve-muscle preparations by a chromatographically purified extract of the dinoflagellate Ostreopsis lenticularis. Brit. J. Pharmacol. 121:1224-1230.

Mizumoto H, Tomaru Y, Takao Y, Shirai Y, Nagasaki K, 2008. Diverse responses of the bivalve-killing dinoflagellate Heterocapsa circularisquama to infection by a single-stranded RNA virus. Appl. Environ. Microbiol. 74:3105-3111.

Monti M, Cecchin E, 2012. Comparative growth of three strains of Ostreopsis ovata at different light intensities with focus on inter-specific allelopathic interactions. Cryptogam. Algol. 33:113-119.

Monti M, Minocci M, Beran A, L. I, 2007. First record of $O s-$ treopsis cfr. ovata on macroalgae in the Northern Adriatic Sea. Mar. Pollut. Bull. 54:598-601.

Moore RE, Scheuer PJ, 1971. Palytoin: a new marine toxin from a coelenterate. Science 172:495-498.

Moore RE, Bartolini G, 1981. Structure of palytoxin. J. Am. Chem. Soc. 103:2491-2494.

Morton SL, Norris DR, Bomber JW, 1992. Effect of temperature, salinity and light-intensity on the growth and seasonality of toxic dinoflagellates associated with ciguatera. J. Exp. Mar. Biol. Ecol. 157:79-90.

Munday R, 2011. Palytoxin toxicology: animal studies. Toxicon 57:470-477.

Murray S, 2010. Benthic dinoflagellates, p. 213-259. In: G. Hallegraeff, C.J.S. Bolch, D.R.A. Hill, I. Jameson, J.-M. LeRoi, A. McMinn, S. Murray, M.F. de Salas and K. Saunders (eds.), Phytoplankton flora of temperate Australia. CSIRO Publishing.

Nagasaki K, Ando M, Imai I, Itakura S, Ishida Y, 1994. Viruslike particles in Heterosigma akashiwo (Raphidophyceae): a possible red tide disintegration mechanism. Mar. Biol. 119:307-312.

Nagasaki K, Yamaguchi M, Imai I, 2000. Algicidal activity of a killer bacterium against the harmful red tide dinoflagellate Heterocapsa circularisquama isolated from Ago Bay, Japan. Nippon Suisan Gakkaishi 66:666-673.

Nakajima I, Oshima Y, Yasumoto T, 1981. Toxicity of benthic dinoflagellates in Okinawa. Bull. Japan Soc. Sci. Fish. 47:1029-1033.

Norris DR, Bomber JW, Balech E, 1985. Benthic dinoflagellates associated with ciguatera from Florida Keys. I. Ostreopsis heptagona sp. nov, pp. 39-44. In: D.M. Anderson, A.W. White and D.G. Baden (eds.), Toxic dinoflagellates. Elsevier.

Okolodkov YB, Campos-Bautista G, Gárate-Lizárraga I, González-González JAG, Hoppenrath M, Arenas V, 2007. Seasonal changes of benthic and epiphytic dinoflagellates in the Veracruz reef zone, Gulf of Mexico. Aquat. Microb. Ecol. 47:223-237.

Onuma Y, Satake M, Ukena T, Roux J, Chanteau S, Rasolofonirina N, Ratsimaloto M, Naoki H, Yasumoto T, 1999. Identification of putative palytoxin as the cause of clupeotoxism. Toxicon 37:55-65.

Pagliara P, Caroppo C, 2012. Toxicity assessment of Amphidinium carterae, Coolia cfr. monotis and Ostreopsis cfr. ovata (Dinophyta) isolated from the northern Ionian Sea (Mediterranean Sea). Toxicon 60:1203-1214.

Parsons ML, Preskitt LB, 2007. A survey of epiphytic dinofla- gellates from the coastal waters of the island of Hawai'i. Harmful Algae 6:658-669.

Pearce I, Marshall JA, Hallegraeff G, 2001. Toxic epiphytic dinoflagellates from east coast Tasmania, Australia, pp. 54 57. In: G. Hallegraeff, S.I. Blackburn, C.J. Bolch and R.J. Lewis (eds.), Harmful algal blooms. Intergovernmental Oceanographic Commission of UNESCO.

Penna A, Vila M, Fraga S, Giacobbe MG, Andreoni F, Riobó P, Vernesi C, 2005. Characterization of Ostreopsis and Coolia (Dinophyceae) isolates in the western Mediterranean Sea based on morphology, toxicity and internal transcribed spacer 5.8s rDNA sequences. J. Phycol. 41:212-225.

Penna A, Fraga S, Battocchi C, Casabianca S, Giacobbe MG, Riobó P, Vernesi C, 2010. A phylogeographical study of the toxic benthic dinoflagellate genus Ostreopsis Schmidt. J. Biogeogr. 37:830-841.

Penna A, Fraga S, Battocchi C, Casabianca S, Perini F, Samuela C, Casabianca A, Riobo P, Giacobbe M, Totti C, Accoroni S, Vila M, Reñé A, Scardi M, Aligizaki K, Nguyen-ngoc L, Vernesi C, 2012. Genetic diversity of the genus Ostreopsis Schmidt: Phylogeographical considerations and molecular methodology applications for field detection in the Mediterranean Sea. Cryptogam. Algol. 33:153-163.

Penna A, Battocchi C, Capellacci S, Fraga S, Aligizaki K, Lemée $\mathrm{R}$, Vernesi C, 2014. Mitochondrial, but not rDNA, genes fail to discriminate dinoflagellate species in the genus Ostreopsis. Harmful Algae 40:40-50.

Perini F, Casabianca A, Battocchi C, Accoroni S, Totti C, Penna A, 2011. New approach using the real-time PCR method for estimation of the toxic marine dinoflagellate Ostreopsis cf. ovata in marine environment. PLoS One 6:e17699.

Pezzolesi L, Guerrini F, Ciminiello P, Dell'Aversano C, Dello Iacovo E, Fattorusso E, Forino M, Tartaglione L, Pistocchi R, 2012. Influence of temperature and salinity on Ostreopsis cf. ovata growth and evaluation of toxin content through HR LC-MS and biological assays. Water Res. 46:82-92.

Pezzolesi L, Pistocchi R, Fratangeli F, Dell'Aversano C, Dello Iacovo E, Tartaglione L, 2014. Growth dynamics in relation to the production of the main cellular components in the toxic dinoflagellate Ostreopsis cf. ovata. Harmful Algae 36:1-10.

Pfannkuchen M, Godrijan J, Maric Pfannkuchen D, Ivesa L, Kruzic P, Ciminiello P, Dell'Aversano C, Dello Iacovo E, Fattorusso E, Forino M, Tartaglione L, Godrijan M, 2012. Toxinproducing Ostreopsis cf. ovata are likely to bloom undetected along coastal areas. Environ. Sci. Technol. 46:5574-5582.

Pfiester LA, 1989. Dinoflagellate sexuality. Int. Rev. Cytol. 114:249-272.

Pfiester LA, Anderson DM, 1987. Dinoflagellate reproduction, p. 611-648. In: F.J.R. Taylor (ed.), The biology of dinoflagellates. Blackwell Science.

Pichierri S, Pezzolesi L, Accoroni S, Guerrini F, Pistocchi R, Totti C, 2015. Growth inhibition of Ostreopsis cf. ovata culture by toxic algal-derived polyunsaturated aldehydes. Proc. CX Nat. Congr. Società Botanica Italiana, Pavia, Italy.

Pinna A, Pezzolesi L, Pistocchi R, Vanucci S, Ciavatta S, Polimene L, 2015. Modelling the stoichiometric regulation of C-rich toxins in marine dinoflagellates. PLoS One 10, e0139046.

Pistocchi R, Pezzolesi L, Guerrini F, Vanucci S, Dell'Aversano C, Fattorusso E, 2011. A review on the effects of environ- 
mental conditions on growth and toxin production of Ostreopsis ovata. Toxicon 57:421-428.

Privitera D, Giussani V, Isola G, Faimali M, Piazza V, Garaventa F, Asnaghi V, Cantamessa E, Cattaneo-Vietti R, Chiantore M, 2012. Toxic effects of Ostreopsis ovata on larvae and juveniles of Paracentrotus lividus. Harmful Algae 18:16-23.

Quod JP, 1994. Ostreopsis mascarenensis sp. nov. (Dinophyceae), dinoflagellé toxique associé a la ciguatera dans 1'Océan Indien. Cryptogam. Algol. 15:243-251.

Randall JE, 2005. Review of Clupeotoxism, an often fatal illness from the consumption of clupeoid fishes. Pac. Sci. 59:73-77.

Raniello R, Lorenti M, Brunet C, Buia MC, 2004. Photosynthetic plasticity of an invasive variety of Caulerpa racemosa in a coastal Mediterranean area: light harvesting capacity and seasonal acclimation. Mar. Ecol.-Prog. Ser. 271:113-120.

Rhodes L, Adamson J, Suzuki T, Briggs L, Garthwaite I, 2000. Toxic marine epiphytic dinoflagellates, Ostreopsis siamensis and Coolia monotis (Dinophyceae), in New Zealand. New Zeal. J. Mar. Fresh. 34:371-383.

Rhodes L, Towers N, Briggs L, Munday R, Adamson J, 2002. Uptake of palytoxin-like compounds by shellfish fed Ostreopsis siamensis (Dinophyceae). N. Z. J. Mar. Freshw. Res. 36:631-636.

Rhodes LL, Smith KF, Munday R, Selwood AI, McNabb PS, Holland PT, Bottein M-Y, 2010. Toxic dinoflagellates (Dinophyceae) from Rarotonga, Cook Islands. Toxicon 56:751-758.

Richlen ML, Lobel PS, 2011. Effects of depth, habitat, and water motion on the abundance and distribution of ciguatera dinoflagellates at Johnston Atoll, Pacific Ocean Mar. Ecol.Prog. Ser. 421:51-66.

Riobó P, Paz B, Franco JM, 2006. Analysis of palytoxin-like in Ostreopsis cultures by liquid chromatography with precolumn derivatization and fluorescence detection. Anal. Chim. Acta 566:217-223.

Riobó P, Paz B, Franco JM, Vázquez JA, Murado MA, 2008. Proposal for a simple and sensitive haemolytic assay for palytoxin Toxicological dynamics, kinetics, ouabain inhibition and thermal stability. Harmful Algae 7:415-429.

Rossi R, Castellano V, Scalco E, Serpe L, Zingone A, Soprano V, 2010. New palytoxin-like molecules in Mediterranean Ostreopsis cf. ovata (dinoflagellates) and in Palythoa tuberculosa detected by liquid chromatography-electrospray ionization time-of-flight mass spectrometry. Toxicon 56:1381-1387.

Rossini GP, Bigiani A, 2011. Palytoxin action on the $\mathrm{Na}+, \mathrm{K}+-$ ATPase and the disruption of ion equilibria in biological systems. Toxicon 57:429-439.

Sagara T, 2008. Profiles of palytoxin-like compounds from the dinoflagellate Ostreopsis sp. isolated from the areas where poisonous fishes were collected. Nippon Suisan Gakkaishi 74:913-914.

Scalco E, Brunet C, Marino F, Rossi R, Soprano V, Zingone A, Montresor M, 2012. Growth and toxicity responses of Mediterranean Ostreopsis cf. ovata to seasonal irradiance and temperature conditions. Harmful Algae 17:25-34.

Schmidt J, 1901. Flora of Koh Chang. Contributions to the knowledge of the vegetation in the Gulf of Siam. Peridiniales. Botanische Tidsskrift 24:212-221.

Selina MS, Orlova TY, 2010. First occurrence of the genus $O s$ treopsis (Dinophyceae) in the Sea of Japan. Bot. Mar. 53:243-249.
Selina MS, Levchenko EV, 2011. Species composition and morphology of dinoflagellates (Dinophyta) of epiphytic assemblages of Peter the Great Bay in the Sea of Japan. Russ. J. Mar. Biol. 37:23-32.

Selina MS, Morozova TV, Vyshkvartsev DI, Orlova TY, 2014. Seasonal dynamics and spatial distribution of epiphytic dinoflagellates in Peter the Great Bay (Sea of Japan) with special emphasis on Ostreopsis species. Harmful Algae 32:1-10.

Shears NT, Ross PM, 2009. Blooms of benthic dinoflagellates of the genus Ostreopsis; an increasing and ecologically important phenomenon on temperate reefs in New Zealand and worldwide. Harmful Algae 8:916-925.

Shears NT, Ross PM, 2010. Toxic cascades: multiple anthropogenic stressors have complex and unanticipated interactive effects on temperate reefs. Ecol. Lett. 13:1149-1159.

Simonini R, Orlandi M, Abbate M, 2011. Is the toxic dinoflagellate Ostreopsis cf. ovata harmful to Mediterranean benthic invertebrates? Evidences from ecotoxicological tests with the polychaete Dinophilus gyrociliatus. Mar. Environ. Res. 72:230-233.

Sosa S, Del Favero G, De Bortoli M, Vita F, Soranzo MR, Beltramo D, Ardizzone M, Tubaro A, 2009. Palytoxin toxicity after acute oral administration in mice. Toxicol. Lett. 191:253-259.

Spatharis S, Dolapsakis NP, Economou-Amilli A, Tsirtsis G, Danielidis DB, 2009. Dynamics of potentially harmful microalgae in a confined Mediterranean Gulf-Assessing the risk of bloom formation. Harmful Algae 8:736-743.

Taniyama S, Arakawa O, Terada M, Nishio S, Takatani T, Mahmud Y, Noguchi T, 2003. Ostreopsis sp., a possible origin of palytoxin (PTX) in parrotfish Scarus ovifrons. Toxicon 42:29-33.

Tarutani K, Nagasaki K, Itakura S, Yamaguchi M, 2001. Isolation of a virus infecting the novel shellfish-killing dinoflagellate Heterocapsa circularisquama. Aquat. Microb. Ecol. 23:103-111.

Tawong W, Yoshimatsu T, Yamaguchi H, Adachi M, 2015. Effects of temperature, salinity and their interaction on growth of benthic dinoflagellates Ostreopsis spp. from Thailand. Harmful Algae 44:37-45.

Taylor FJR, 1979. The description of the benthic dinoflagellate associated with maitotoxin and ciguatoxin, including observations on Hawaiian material, p. 71-77. In: D.L. Taylor and H.H. Seliger (eds.), Toxic dinoflagellate blooms. Elsevier Scientific.

Tichadou L, Glaizal M, Armengaud A, Grossel H, Lemée R, Kantin R, Lasalle JL, Drouet G, Rambaud L, Malfait P, de Haro L, 2010. Health impact of unicellular algae of the $O_{s-}$ treopsis genus blooms in the Mediterranean Sea: experience of the French Mediterranean coast surveillance network from 2006 to 2009. Clinical Toxicology 48:839-844.

Tognetto L, Bellato S, Moro I, Andreoli C, 1995. Occurrence of Ostreopsis ovata (Dinophyceae) in the Tyrrhenian Sea during Summer 1994. Bot. Mar. 38:291-295.

Tosteson TR, 1995. The diversity and origins of toxins in ciguatera fish poisoning. P. R. Health Sci. J. 14:117-129.

Totti C, Accoroni S, Cerino F, Cucchiari E, Romagnoli T, 2010. Ostreopsis ovata bloom along the Conero Riviera (northern Adriatic Sea): Relationships with environmental conditions and substrata. Harmful Algae 9:233-239. 
Tubaro A, Del Favero G, Beltramo D, Ardizzone M, Forino M, De Bortoli M, Pelin M, Poli M, Bignami G, Ciminiello P, Sosa S, 2011. Acute oral toxicity in mice of a new palytoxin analog: 42-Hydroxy-palytoxin. Toxicon 57:755-763.

Tubaro A, Del Favero G, Pelin M, Bignami G, Poli M, 2014. Palytoxin and analogues: biological effects and detection, $\mathrm{p}$. 741-772. In: L.M. Botana (ed.), Seafood and freshwater toxins: pharmacology, physiology, and detection, 3rd edition. CRC Press.

Turki S, 2005. Distribution of toxic dinoflagellates along the leaves of seagrass Posidonia oceanica and Cymodocea nodosa from the Gulf of Tunis. Cah. Biol. Mar. 46:29-34.

Turki S, Harzallah A, Sammari C, 2006. Occurrence of harmful dinoflagellates in two different Tunisian ecosystems: the lake of Bizerte and the Gulf of Gabes. Cah. Biol. Mar. 47:253-259.

Uchida H, Taira Y, Yasumoto T, 2013. Structural elucidation of palytoxin analogs produced by the dinoflagellate Ostreopsis ovata IK2 strain by complementary use of positive and negative ion liquid chromatography/quadrupole time-of-flight mass spectrometry. Rapid Commun. Mass Spectrom. 27:1999-2008.

Ukena T, Satake M, Usami M, Oshima Y, Naoki H, Fujita T, Kan Y, Yasumoto T, 2001. Structure elucidation of ostreocin D, a palytoxin analog isolated from the dinoflagellate Ostreopsis siamensis. Biosci. Biotechnol. Biochem. 65:2585-2588.

Ungaro N, Marano G, Pastorelli AM, Marzano MC, Pompei M, 2005. Presenza di Ostreopsidiaceae nel basso Adriatico, Rapporti ISTISAN 05/29. Istituto Superiore di Sanità, Roma.

Usami M, Satake M, Ishida S, Inoue A, Kan Y, Yasumoto T, 1995. Palytoxin analogs from the dinoflagellate Ostreopsis siamensis. J. Am. Chem. Soc. 117:5389-5390.

Vanucci S, Guerrini F, Pezzolesi L, Dell'Aversano C, Ciminiello $\mathrm{P}$, Pistocchi R, 2012a. Cell growth and toxins' content of $O s$ - treopsis cf. ovata in presence and absence of associated bacteria. Cryptogam. Algol. 33:105-112.

Vanucci S, Pezzolesi L, Pistocchi R, Ciminiello P, Dell'Aversano C, Dello Iacovo E, Fattorusso E, Tartaglione L, Guerrini F, 2012b. Nitrogen and phosphorus limitation effects on cell growth, biovolume, and toxin production in Ostreopsis cf. ovata. Harmful Algae 15:78-90.

Vidyarathna NK, Granéli E, 2013. Physiological responses of Ostreopsis ovata to changes in $\mathrm{N}$ and $\mathrm{P}$ availability and temperature increase. Harmful Algae 21-22:54-63.

Vila M, Garcés E, Masó M, 2001. Potentially toxic epiphytic dinoflagellate assemblages on macroalgae in the NW Mediterranean. Aquat. Microb. Ecol. 26(1):51-60.

Wall D, 1975. Taxonomy and cysts of red-tide dinoflagellates, p. 249-255. In: V.R. LoCicero (ed.), First international conference on toxic dinoflagellate blooms. Massachusetts Science and TechnologyFoundation, Wakefield.

Wattenberg EV, 2011. Modulation of protein kinase signaling cascades by palytoxin. Toxicon 57:440-448.

Yasumoto T, 1998. Fish poisoning due to toxins of microalgal origins in the Pacific. Toxicon 36:1515-1518.

Yasumoto T, Yasumura D, Ohizumi Y, Takahashi M, Alcala AC, Alcala LC, 1986. Palytoxin in two species of Xanthid crab from the Philippines. Agric. Biol. Chem. 50:163-167.

Yasumoto T, Seino N, Murakami Y, Murata M, 1987. Toxins produced by benthic dinoflagellates. Biol. Bull. 172:128-131.

Yamaguchi H, Tomori Y, Tanimoto Y, Oku O, Adachi M, 2014. Evaluation of the effects of light intensity on growth of the benthic dinoflagellate Ostreopsis sp. 1 using a newly developed photoirradiation-culture system and a novel regression analytical method. Harmful Algae 39:48-54.

Zhang Q, Hu G, 2011. Effect of nitrogen to phosphorus ratios on cell proliferation in marine micro algae. Chin. J. Oceanol. Limnol. 29:739-745. 